\title{
Problems of online learning in a borderland of Indonesia in the COVID-19 pandemic
}

\author{
A. Sultoni*, E.P. Priyatni, A.M. Nasih, A. Zahro, Juharyanto \& Ibrohim \\ Universitas Negeri Malang, Malang, Indonesia
}

\begin{abstract}
The COVID-19 pandemic in Indonesia has altered dramatically many aspects of life. In formal education, the Ministry of Education issued a policy instructing schooling sectors to implement online learning to prevent students from contracting COVID-19. Therefore, the aim of this study was to portray problems emerging in online learning at senior high schools in a borderland of Indonesia: the province of North Kalimantan. Data was collected in September 2020 through an online open questionnaire asking questions to 251 teachers at senior high schools throughout the regencies. Data was analyzed through descriptive quantitative and qualitative frameworks. The results revealed that the emerging problems of online learning included internet networks, internet data, learning devices, student attitudes, parent attitudes, learning evaluations, teaching methods, the literacy of information technology, and student comprehension. To conclude, the most noticeable problems are internet access, competency in online learning, and student attitudes.
\end{abstract}

Keywords: online learning, borderland, COVID-19 pandemic, Senior High School

\section{INTRODUCTION}

Coronavirus disease (COVID-19) was first reported in Wuhan, China, in December 2019 by Wuhan Municipal Health Commission. This deadly virus transmits from person to person and has killed millions of people and became a pandemic in more than 190 countries ( $\mathrm{Li}$ et al. 2020; Huang et al. 2020; WHO 2020). In Indonesia, the case of COVID-19 is first confirmed in March 2020 and then infected more than 433,000 people. The virus spread over all provinces and caused lockdown in many provinces (Gugus Tugas 2020).

The COVID-19 pandemic in Indonesia drastically changed many aspects of life, not only in the economy but also in tourism, religion, education and society. In education, the Ministry of Education and Culture closed almost all schools and implemented online learning to prevent COVID-19 transmission (Kemdikbud 2020; media Indonesia 2020). The implementation of online learning at a national scale brought opportunity (Gonzalez et al. 2020) and hindrance (Yang 2020). However, the implementation of emergency online learning in remote areas seemed to cause more hindrance and problems than opportunities.

Online learning is a kind of learning which depends on the availability of information technology. Internet access and technological devices, such as smartphones and computers are crucial because without them, it is likely impossible to implement online learning (Singh \& Thurman 2019; Adedoyin \& Soykan 2020). Digital competence in operating the information technology plays important roles in effective online learning (Ferrari 2012). Another aspect that affected online learning is teacher competency in designing effective and interesting online learning. One of the crucial issues is how to control cheating with the limited supervision of teachers (Arkorful \& Abaidoo 2014).

\footnotetext{
*Corresponding author: achmad.sultoni.fs@um.ac.id
} 
Activities of teaching and learning in online learning can be divided into synchronous and asynchronous. Synchronous learning using video conference tools (such as Zoom and Google Meet) needs good internet connectivity and comes at a high cost. However, asynchronous learning through videos of recorded lectures or PowerPoint presentations costs less money and does not always require good internet access (Azlan et al. 2020; Crawford et al. 2020; Patricia 2020).

Problems and hindrances in online learning due to the COVID-19 pandemic must be urgently investigated. The study's focus is not only limited to kind of problems, but also the intensity of problems and objects of problems. The investigation results are important for the government to provide policies and rules of effective education for citizens. Studies on problems of online learning in Indonesia are abundant, some focused on university (Hamid et al. 2020; Rachmawati et al. 2020, Agung et al. 2020), in elementary schools (Purwanto et al. 2020, Putria et al. 2020), and for disabled students (Rof'ah et al. 2020). Studies on the problem of online learning in remote areas seem sparse both in number and scope. For instance, online learning problems at elementary schools in a rural area of Bojonegoro, East Java (Setiawan \& Iasha 2020), and comparisons of online learning in urban and remote areas are limited (Sulisworo et al. 2020).

The present study investigated online learning problems in senior high school due to the COVID-19 pandemic in Indonesia's borderland, namely North Kalimantan. This location was chosen to portray the worst effects of emergency online learning in Indonesia since North Kalimantan is the newest province in Indonesia (established in 2013) and is located in a relatively remote area near Malaysia (Kaltaraprov 2020).

\section{METHODS}

In this study, the subjects were 251 teachers at senior high school in North Kalimantan. All have obtained the certificate of a professional educator. They are largely teachers at public schools, both vocational and non-vocational schools, throughout North Kalimantan (Tarakan, Bulungan, Malinau, Nunukan, and Tana Tidung). Their last education mainly included graduate level courses though some graduated from postgraduate studies and have taught for more than ten years on average.

Data was collected in September 2020 through open questionnaire via a Google form. The respondents could answer more than one problem of online learning they encountered. All data was analyzed through qualitative analysis (Miles et al. 2014) and simple a descriptive statistic. At first, all data was classified according to types of online learning problems. Then the percentage of each problem is formulated and a conclusion is drawn.

\section{RESULTS AND DISCUSSION}

The respondents wrote 485 problems emerging in online learning, which are classified into nine problems. The problems consisted of internet access and devices, student and parent attitudes, and literacy in online learning. Table 1 explains the problems.

Table 2 shows that the problems of online learning due to the COVID-19 pandemic consist of the availability of the internet network, the unavailability of internet data, the unavailability of learning devices, student attitudes, parent attitudes, the evaluation of learning, the teaching method, the literacy of technology and student understanding. It is obvious from Table 2 that the main problems of online learning in the borderland are internet networks, internet data and student attitudes. On the contrary, parent attitudes, technological literacy and student understanding are minor problems with minimal occurrences. In detail, the percentage of each online learning problem is described in figure 1.

All problems of online learning described in Figure 1 can be classified in a more concise way. Problems of internet network and internet data are related to internet access, whereas problems of 
Table 1. The types of problems of online learning in the borderland.

\begin{tabular}{|c|c|c|c|}
\hline No & Type of problems & Occurrence & Details \\
\hline 1 & Internet network & 138 times & $\begin{array}{l}\text { Mainly unstable internet networks. In some cases, } \\
\text { there is no network at all. }\end{array}$ \\
\hline 2 & Internet data & 91 times & $\begin{array}{l}\text { Students did not have internet data or Wi-Fi access. In } \\
\text { some towns, sometimes electricity is off. }\end{array}$ \\
\hline 3 & Learning devices & 58 times & $\begin{array}{l}\text { Students did not have smartphones or laptops due to } \\
\text { economic factors. }\end{array}$ \\
\hline 4 & Attitude of students & 102 times & $\begin{array}{l}\text { This problem includes absences in a virtual class, lack } \\
\text { of motivation, and lack of discipline in joining classes } \\
\text { and doing homework. Students also did not do home- } \\
\text { work, got bored, or give few responses in a virtual } \\
\text { class. }\end{array}$ \\
\hline 5 & Attitude of parents & 8 times & $\begin{array}{l}\text { Some parents pay no attention to online learning, and } \\
\text { even ask students to work with them. }\end{array}$ \\
\hline 6 & Learning evaluation & 22 times & $\begin{array}{l}\text { Teachers find it is difficult to evaluate students } \\
\text { achievements, especially in the aspect of moral and } \\
\text { skill. }\end{array}$ \\
\hline 7 & Teaching method & 52 times & $\begin{array}{l}\text { It is hard for teachers to determine effective } \\
\text { ways/methods in teaching and to manage time well. } \\
\text { Teachers also cannot control students' learning activi- } \\
\text { ties. These conditions, in turn, affect the achievement } \\
\text { of learning objectives. }\end{array}$ \\
\hline 8 & Literacy of technology & 6 times & $\begin{array}{l}\text { Some teachers and students did not understand the } \\
\text { technology of online learning. }\end{array}$ \\
\hline 9 & \multicolumn{3}{|c|}{ Total number of problems: 485} \\
\hline
\end{tabular}

Table 2. Percentage of online learning problems in the borderland.

\begin{tabular}{llll}
\hline Number & Type of Problems & Occurrence & Percentage \\
\hline 1 & internet network & 138 & $28.45 \%$ \\
2 & internet data & 91 & $18.76 \%$ \\
3 & learning devices & 58 & $11.96 \%$ \\
4 & student attitude & 102 & $21.03 \%$ \\
5 & parent attitude & 8 & $1.65 \%$ \\
6 & learning evaluation & 22 & $4.54 \%$ \\
7 & teaching method & 52 & $10.72 \%$ \\
8 & literacy of technology & 6 & $1.24 \%$ \\
9 & students understanding & 8 & $1.65 \%$ \\
& Total: & 485 & $100 \%$ \\
\hline
\end{tabular}

learning evaluation, teaching methods, literacy of information technology, and student understanding can be categorized as the competency of online learning. In other words, problems of online learning consist of internet access, learning devices, the competency of online learning, student attitudes and parent attitudes. The changes in problem types, in turn, change the percentage of some problems. Internet access becomes the biggest problem of online learning in North Kalimantan. The changes are portrayed in Figure 1.

Nine problems emerging in emergency online learning in North Kalimantan are possibly related to each other. Student difficulties in accessing the internet (i.e., unstable internet network, no internet data, and no learning devices) negatively affect their attitude to online learning; for instance, they 


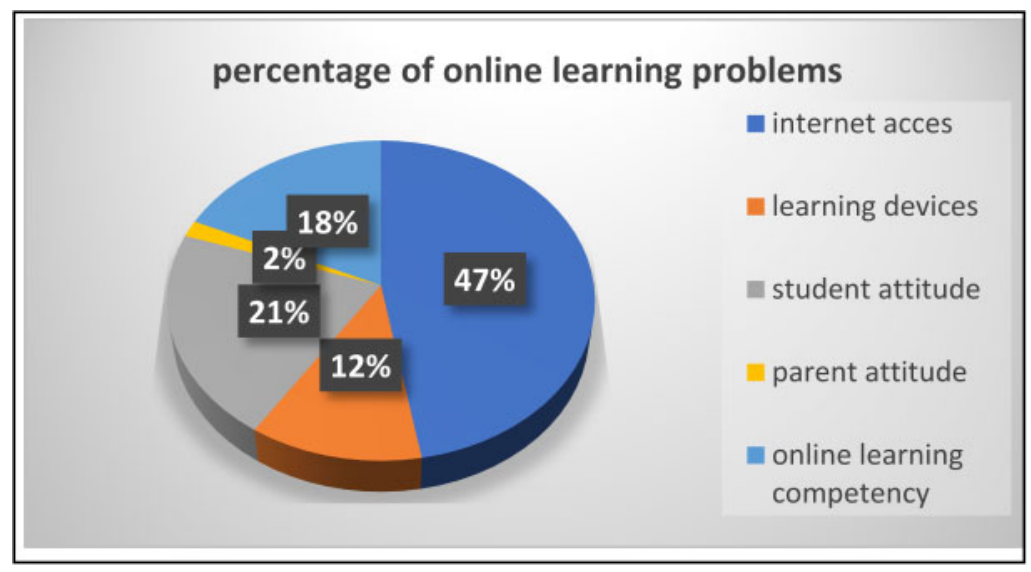

Figure 1. Types of online problems and their percentage in brief.

were frequently absent in online learning and were acting indisciplined. This phrase corresponds to Dhawan's (2020) statement that students with no internet access and no smartphones/laptops are in big trouble in online learning, since they lose the opportunity for learning. Adedoyin \& Soykan (2020) explained that internet access's main factors are socio-economic and relating to the internet network. Students from low socio-economic groups will be left behind in online learning.

That some teachers in North Kalimantan are less competent in online learning due to the COVID19 pandemic confirms previous research results (Setiawan \& Iasha 2020; König et al. 2020). König et al. reported that new teachers (that are "digital natives") in Germany have not developed digital ability in online teaching. Moreover, many schools in Germany are left behind in implementing information and communication technology (ICT). The finding is also in accordance with Dhawan's (2020) statement that it is hard for teachers to change mode, methodology and time management from offline to online learning. In addition, Adedoyin \& Soykan (2020) said that most teachers are not ready to design qualified learning activities.

Internet access becomes the main problem of online learning in remote areas such as in North Kalimantan. Previous research by Setiawan and Iasha (2020) showed that the big problem of online learning in a rural area of Bojonegoro was an unstable internet network. The condition also happens beyond COVID-19 pandemic (Rao et al. 2011). The statement corresponds with a previous study that online learning's common problem in remote areas is a slow internet connection (AISR 2006) and information technology mastery (Ramanujam 2002).

Other finding indicated that students perceived negatively online learning corroborates research in Ghana. Aboagye et al. (2020) found that students in Ghana would choose to cancel online learning in the COVID-19 pandemic if they could. The negative attitude to online learning is correlated with a middle to a high economic level. Sindiani et al. (2020) reported that medical students in Jordan preferred traditional face-to-face teaching to online teaching. Similarly, students at dental school in China had low progress in synchronous online prosthodontic courses (Yang 2020). Surrounding distractions may cause this negative attitude, such as: difficulty in accessing the internet, the virtual classroom, low motivation, low engagement to online learning, deficient smart phones/laptops and inadequate competency in using information technology (Elahi 2012; Zhang et al. 2020). On the contrary, research by Qazi et al. (2020) revealed that students in Brunei and Pakistan, with ease of access to the internet and affordability of mobile phones considered online learning to be a positive thing. This positive attitude is partly because of students' intention and good acceptance (Yakubu \& Dasuki 2019; Kemp et al. 2019; Tarhini et al. 2016). 


\section{CONCLUSION}

The emerging problems of sudden online learning in borderland (North Kalimantan) are internet access (internet network and internet data), competency in online learning, student attitudes, learning devices, and parent attitudes. The most noticeable problems are the access of the internet and competency of online learning. As an implication, the government is encouraged to build an infrastructure of the internet connection in North Kalimantan and hold training in online learning to provide qualified education in remote regions.

\section{REFERENCES}

Aboagye, Emmanuel, Joseph Anthony Yawson, Kofi Nyantakyi Appiah. 2020. COVID-19 and E-Learning: The Challenges of Students in Tertiary Institutions. Social Educa-tion Research, Volume 1 Issue 1, 109-115, DOI: https://doi.org/10.37256/ser.122020422.

Adedoyin, Olasile Babatunde, \& Emrah Soykan. 2020. COVID-19 pandemic and online learning: the challenges and opportunities, Interactive Learning Environments, DOI: 10.1080/10494820.2020.1813180

Agung, Antonius Setyawan Sugeng Nur, Monika Widyastuti Surtikanti, \& Charito A Quinones. 2020. Students' Perception of Online Learning during COVID-19 Pandemic: A Case Study on the English Students of STKIP Pamane Talino. SOSHUM Jurnal Sosial dan Humaniora [Journal of Social Sciences and Humanities] Volume 10, Number 2, 2020.

Arkorful, V., \& Abaidoo, N. 2014. The Role Of E-Learning: Advantages and Disadvantages of Its Adoption in Higher Education. International Journal of Education and Research, 2 (12), 397 - 410.

Australian Institute for Social Research (AISR). The Digital Divide: Barriers to E-learning. Final Report presented to Digital Bridge Unit, Science Technology and Innovation Directorate. University of Adelaide, Australia, 2006.

Azlan, Che Ahmad, Jeannie Hsiu Ding Wong, Li Kuo Tan,Muhammad Shahrun Nizam A.D. Huri,Ngie Min Ung, Vinod Pallath,Christina Phoay Lay Tan,Chai Hong Yeong, Kwan Hoong Ng. 2020. Teaching and learning of postgraduate medical physics using Internet-based e-learning during the COVID-19 pandemic - A case study from Malay-sia. Physica Medica, 80 (2020) 10-16, Published by Elsevier, https://doi.org/10.1016/j.ejmp.2020.10.002.

Crawford, J., Butler-Henderson, K., Rudolph, J., \& Glowatz, M. 2020. COVID-19: 20 Countries' Higher Education Intra-Period Digital Pedagogy Responses. Journal of Applied Teaching and Learning (JALT), 3(1). https://doi.org/10.37074/jalt.2020.3.1.7

Dhawan, Shivangi. 2020. Online Learning: A Panacea in the Time of COVID-19 Crisis. Journal of Educational Technology Systems, Vol. 49(1) 5-22, DOI: 10.1177/0047239520934018.

Elahi, Rashid M Uzma. 2012. Use of educational technology in promoting distance education. Turkish Online Journal of Distance Education-TOJDE, January, Volume: 13 Number: 1 Article 3; :79-86. ISSN 1302-6488.

Ferrari, Anusca. 2012. Digital Competence in Practice: An Analysis of Frameworks. Euro-pean Commission Joint Research Centre, Institute for Prospective Technological Studies, doi:10.2791/82116.

Gonzalez T, de la Rubia MA, Hincz KP, Comas-Lopez M, Subirats L, Fort S, et al. 2020. Influence of COVID-19 confinement on students' performance in higher education. PLOS ONE 15(10): e0239490. https://doi.org/10.1371/journal.pone.0239490

Huang, C., Wang, Y., Li, X., Ren, L., Zhao, J., Hu, Y., Zhang, L., Fan, G., Xu, J., Gu, X., \& Cheng, Z. 2020. Clinical features of patients infected with 2019 novel coronavirus in Wuhan, China. The Lancet, 395(10223), 497-506. https://doi.org/10.1016/S0140-6736(20)30183-5

Kemp, A., Palmer, E., and Strelan, P. (2019), A taxonomy of factors affecting attitudes towards educational technologies for use with technology acceptance models. British Journal Education Technology, 50, 2394 2413. doi:10.1111/bjet.12833

König, Johannes, Daniela J. Jäger-Biela \& Nina Glutsch. 2020. Adapting to Online Teaching During COVID-19 School Closure: Teacher Education and Teacher Competence Effects Among Early Career Teachers in Germany. European Journal of Teacher Education, 43:4, 608-622, DOI: $10.1080 / 02619768.2020 .1809650$.

Li, Q., Guan, X., Wu, P., Wang, X., Zhou, L., Tong, Y., Ren, R., Leung, K. S., Lau, E. H., Wong, J. Y., \& Xing, X. (2020). Early transmission dynamics in Wuhan, China, of novel coronavirus-infected pneumonia. New England Journal of Medicine, 382,1199-1207. https://doi.org/10.1056/NEJMoa2001316 
Miles, M. B., Huberman, A. M. \& Saldana, J. 2014. Qualitative data analysis: An expanded sourcebook (3rd ed.). London: SAGE.

Patricia. A. 2020. College Student' Use and Acceptance of Emergency Online Learning Due to COVID-19, International Journal of Educational Research Open, doi: https://doi.org/10.1016/j.ijedro.2020.10001

Putria, Hilna, \& Luthfi Hamdani Maula, Din Azwar Uswatun. 2020. Analisis Proses Pembelajaran dalam Jaringan (DARING) Masa Pandemi COVID-19 Pada Guru Sekolah Dasar. Jurnal Basicedu, Vol 4 No 4 2020, 861-872. DOI: https://doi.org/10.31004/basicedu.v4i4.460.

Ramanujam, P. Renga. 2002. Distance Open Learning: Challenges to Developing Countries. Delhi, India: Shipra Publications.

Rao, K., Eady, M., \& Edelen-Smith, P. 2011. Creating virtual classrooms for rural and remote communities. Phi Delta Kappan. 92(6), 22-27.

Setiawan, Bramianto \& Vina Iasha. 2020. COVID-19 Pandemic: The Influence of Full-Online Learning for Elementary School in Rural Areas. Jurnal Pendidikan Sekolah Dasar (JPSD), Vol. 6 No. 2, September 2020, 114-123. DOI: Http://Dx.Doi.Org/10.30870/Jpsd.V6i2.8400.

Sindiani, Amer Mahmoud, Nail Obeidat, Eman Alshdaifat, Lina Elsalem, Mustafa M.Alwani, Hasan Rawashdeh, Ahmad S.Fares, Tamara Alalawne, and Loai Issa Tawalbeh. 2020. Distance education during the COVID-19 outbreak: A cross-sectional study among medical students in North of Jordan. Annals of Medicine and Surgery 59 (2020) 186-194, https://doi.org/10.1016/j.amsu.2020.09.036.

Sulisworo, Dwi, Dian Artha Kusumaningtyas, Agnes Bergita Anomeisa, Wahyuningsih \& Widya Rahmadhani. Perceptions of Online Learning Experiences Between Students in Urban and Remote Areas: Case Study in Indonesia. International Journal of Scientific \& Technology Research, vol 9, Issue 02, February 2020, 4850-4854, Issn 2277-8616 4850 IJSTR@2020.

Tarhini, A., Hone, K., Liu, X., \& Tarhini, T. 2016. Examining the moderating effect of individual-level cultural values on users' acceptance of E-learning in developing countries: a structural equation modeling of an extended technology acceptance model. Interactive Learning Environments, 25(3), 306-328, doi:10.1080/10494820.2015.1122635

Vandana Singh \& Alexander Thurman. 2019. How Many Ways Can We Define Online Learning? A Systematic Literature Review of Definitions of Online Learning (1988-2018), American Journal of Distance Education, 33:4, 289-306, DOI: 10.1080/08923647.2019.1663082

Yakubu, M. N., \& Dasuki, S. I. 2019. Factors affecting the adoption of e-learning technologies among higher education students in Nigeria: A structural equation modeling approach. Information Development, 35(3), 492-502. https://doi.org/10.1177/0266666918765907

Yang, Xu, Deli Li, Xiaoqiang Liu, Jianguo Tan. 2020. Learner behaviors in synchronous online prosthodontic education during the 2020 COVID-19 pandemic, The Journal of Prosthetic Dentistry, ISSN 0022-3913, https://doi.org/10.1016/j.prosdent.2020.08.004.

Zhang, W.; Wang, Y.; Yang, L.; Wang, C. 2020. Suspending Classes Without Stopping Learning: China's Education Emergency Management Policy in the COVID-19 Outbreak. J. Risk Financial Manag. 13, 55. https://covid19.go.id/peta-sebaran

https://kaltaraprov.go.id/profil/sejarah.

https://mediaindonesia.com/read/detail/327729-tegakkan-ketentuan-sesuai-skb-4-menteri

https://www.kemdikbud.go.id/main/blog/2020/08/penyesuaian-keputusan-bersama-empat-menteri-tentangpanduan-pembelajaran-di-masa-pandemi-covid19

https://www.who.int/emergencies/diseases/novel-coronavirus-2019 